\title{
The Shifting Parameters of Nationality
}

\section{Kristin Henrard ${ }^{1}$}

Published online: 30 November 2018

(C) The Author(s) 2018

\begin{abstract}
This article has two interrelated aims. First, the article goes beyond law and places the discussions on nationality in the broader literature on citizenship, also drawing on social sciences, political theory and moral philosophy. The ensuing conceptual, historical and multi-disciplinary account highlights the long pedigree of the idea of citizenship, the manifold conceptions of citizenship that have developed over time (including supra-national, sub-national and transnational citizenship). The article demonstrates how the changing spatialities of citizenship culminated in a focus on the nation-state, and the emergence of legal citizenship or nationality, reflecting the legal bond between an individual and a state. It was also noted that in several respects the parameters of nationality keep changing. More particularly, four developments have been highlighted that circumscribe the sovereign right of states to determine who are their nationals, both legally and through de facto pressures. Secondly, this contribution provides the overarching framework for the special issue while identifying the salient discussion points regarding nationality and international law that will be teased out in the articles of the special issue. The article ends with a brief overview of the articles that make up the special issue.
\end{abstract}

Keywords (Legal and substantive) citizenship - Membership of polity · Nationstate $\cdot$ Shifting spatialities $\cdot$ Legal bond between state and individual $\cdot$ Statelessness . Dual nationality $\cdot$ Rights

\section{Introduction}

This introductory article to NILR's special issue focused on nationality and international law has two interrelated aims. First, the article goes beyond law and places the discussions on nationality in the broader literature on citizenship, also drawing on social sciences, political theory and moral philosophy. The ensuing conceptual, historical and multi-disciplinary account highlights the long pedigree of the idea of

Kristin Henrard

Henrard@law.eur.nl

1 Erasmus School of Law, Erasmus University Rotterdam, Rotterdam, The Netherlands 
citizenship, the manifold conceptions of citizenship that have developed over time (including supra-national, sub-national and transnational citizenship) and its relevance for a good understanding of nationality. ${ }^{1}$ Secondly, this contribution provides the overarching framework for the special issue while identifying the salient discussion points regarding nationality and international law that will be teased out in the articles of the special issue.

A recurring theme throughout this article is the extent to which questions about the core notion of nationality, and the special bond that is supposed to represent between a natural person and a state, can be seen to inform choices about modes of acquisition and legitimate instances of deprivation, as well as rights and duties 'reserved' for nationals. ${ }^{2}$ Indeed, the type of criteria set for acquisition of nationality arguably allows one to reflect on the bond nationality is supposed to represent, while the protections reserved for nationals similarly offer some indication of the nature of that bond. ${ }^{3}$ The importance of these rights and additional protection layers contingent on nationality furthermore signal the importance of having a nationality. However, when (human) rights are increasingly detached from nationality, what explains the sustained vigor of the fight against statelessness, the increasing recognition of a human right to a nationality and the limited possibilities for deprivations of nationality (also when fighting terrorism)? All of the above themes tie in with controversies and challenges regarding dual or even multiple nationalities, both from the perspective of public and private international law. Another central theme, not only for this article but also for the special issue as a whole, concerns the implications of the changed circumstances of the current mobile world with its multiple migration streams, as compared to the times when nationality as a legal category was conceived, and most people lived and died in the area where they were born. To what extent and in what way do these changed circumstances affect the way we understand nationality, the special bond it is supposed to reflect (including the degree to which it can be commodified), and its ongoing relevance as connecting factor for rights in international law.

The article is structured in five parts. The first part (Sect. 2) provides a historical conceptual account of the development of the multi-dimensional notion of citizenship and its shifting spatialities, until the era in which the nation-state became the central point of reference, and nationality as legal concept emerged. The state may still be the central point of reference, the reality of multiple levels of governance

\footnotetext{
1 Liebich (2010) highlights in this respect that nationality laws and changes in this respect are inspired by (changing) conceptions of citizenship. Note that in the literature at times the distinction is made within the legal field between citizenship and nationality with the former referring to the status and rights in terms of national law (within a particular state), whereas the latter would concern the status and rights in terms of international law, see, inter alia, Rubenstein (2004), p. 3.

2 This close interrelation is nicely captured by Crawford (2012) who argues that: 'nationality is a legal bond having as its basis a social fact of attachment, a genuine connection of existence, interests and sentiments, together with the existence of reciprocal rights and duties', p. 513.

3 The institute of diplomatic protection may not translate in an actual right of nationals, it does constitute an additional layer of protection for nationals, and is thus similarly relevant for the study of nationality in international law.
} 
translate into multiple, interrelated levels of citizenship, including EU citizenship. The first part thus clarifies the terminological choices made in this article, ${ }^{4}$ more particularly regarding the use of the terms 'citizenship' and 'nationality'. The second part (Sect. 3) continues with a focus on the state as the (most) relevant political community, and further elaborates on the multi-dimensional notion of citizenship in reference to membership of the state. Subsequently, the analysis of the third part (Sect. 4) zooms in on nationality as the legal bond between individual and state, while taking note on the one hand of the impact of the expanding human rights paradigm, constraining state sovereignty in ever more domains, and on the other the reality of extensive migration, resulting in a 'mobile world'. The analysis in this part takes up four interrelated themes, namely requirements for acquisition of nationality (4.1), the ensuing rights/protections and obligations (4.2), the right to a nationality/ fight against statelessness (4.3) and dual nationality (4.4). In view of the respective focus of the following articles, ${ }^{5}$ the discussion here will be more elaborate on (shifts in) rights and obligations that hinge on nationality. Some concluding observations (Sect. 5) on the lines developed in this article are followed by a fifth part (Sect. 6) which explains the composition of the special issue.

\section{A Historical Conceptual Account of the Notion of Citizenship and Its Relation to 'Nationality'}

The notion of 'citizenship' has triggered a burgeoning literature from a wide variety of disciplines, including political theory, sociology, political philosophy, and law. Notwithstanding the divergent points of view that are visible in that literature, broad agreement about the core meaning of citizenship does emerge. Citizenship refers to membership of a polity, of a political community, and thus revolves around questions of inclusion and-as the other side of the coin-exclusion. ${ }^{6}$ Another central theme throughout the literature is the fundamental role of equality in relation to citizenship, not only the entitlement of citizens to equal rights, but also the expanding role of the prohibition of discrimination in relation to access and deprivation of citizenship. $^{7}$

The state may still be the dominant point of reference for discussions of citizenship, the notion citizenship has ancient origins. ${ }^{8}$ A terminological clarification is called for prior to delving into a historical account of the shifts over time of the (spatiality of the) most relevant political community. The literature reveals that some authors use the terms citizenship and nationality interchangeably, while others use

\footnotetext{
${ }^{4}$ In line with the overall lack of consistency in the literature, other authors in this special issue may use the terms differently. That is each time explained in each respective article.

5 The thematic analysis will each time make cross-references to the (most) relevant contributions in this special issue on the topic concerned.

6 Joppke (2017), p. 392; Shachar et al. (2017), p. 5.

7 Rubenstein (2004), pp. 5-6.

8 Some even go back to first permanent settlements in the Neo-lithic period: inter alia, Diener (2017) p. 37.
} 
both terms to describe the relationship between an individual and the state, but in reference to different legal forums: citizenship would concern the national legal forum, whereas nationality the international legal forum. ${ }^{9}$ As will be explained more fully below, non-legal disciplines distinguish between various dimensions of citizenship, ${ }^{10}$ one of which concerns the legal bond between an individual and a state, the others capture substantive citizenship. In this article the term 'nationality' is used when referring to the legal bond between an individual and the state, while 'citizenship' denotes the broader term, also including the other dimensions of membership.

Importantly, throughout the rescaling of citizenship over time, in the sense that citizenship was defined in relation to varied politico-territorial structures (city-polis, empire, nation-state etc.), there have always been alternative scales of citizenship. In the words of Diener: 'communities of belonging and obligation have existed outside and across the dominant politico-territorial structures of all eras'. ${ }^{11}$ This reality of intersecting, multiple levels of community ${ }^{12}$ and membership is ever more visible at present with power shifting away from the state to the local, regional and supranational level, ${ }^{13}$ translating into multi-level governance.

The historical conceptual enquiry first turns to the shifting spatialities of the polity or political community (2.1), to subsequently elaborate on the meaning and underlying rational of 'membership' (2.2).

\subsection{The Changing Spatialities of 'Political Community'14}

As was already highlighted above, historical accounts of thinking in terms of polities, of politico-territorial structures and membership thereof reveal that the contours of the polity have rescaled over time in a non-linear fashion. ${ }^{15}$ Strikingly, while there have always been alternative 'communities of belonging and obligation', the most central reference points for citizenship have had a geographic basis. ${ }^{16}$ Remarkable differences in the scale of the relevant territorial structures can be noted.

\footnotetext{
9 Rubenstein (2004), p. 3.

${ }^{10}$ McMahon (2012), pp. 2-3; Bloemraad et al. (2008), pp. 154-155. See also Bauböck (2010), pp. 847848.

11 Diener (2017), p. 38.

12 Shachar et al. (2017), p. 7.

13 See, inter alia, Sassen (2002), p. 277. See also the exploration of a global and cosmopolitan citizenship in Rubenstein and Adler (2000), p. 519; Linklater (2002), p. 323.

14 In this historical overview the focus will be on Europe, because the central point of reference, the nation-state was originally devised in Western Europe and later, more particularly after 1815 spread across the world (for a detailed discussion on the basis of an extensive dataset comprising 145 states: Wimmer and Feinstein (2010)). Various trajectories of nation-state creation have been distinguished, such as (de)colonisation (Laakso and Olukoshi (1996), pp. 12-16), the collapse of land-based empires, nationalist secession (Yugoslavia, Mexico), and unification movements (Germany, Yemen). Wimmer and Feinstein identify an 'imitation process driven by the extra-ordinary success and global dominance of the first nation-states' (Wimmer and Feinstein (2010), p. 785) while pointing to the required shift in the balance of power to enable nation-state creation: ibid).

15 For detailed accounts of these historical developments, see Diener (2017), p. 38 and Bosniak (2000).

16 Bauböck and Giraudon (2009), p. 448; Bloemraad et al. (2008), p. 154. Diener (2017) refers in this respect to the 'dominant politico-territorial structures of all eras', p. 38.
} 
Ideas of citizenship were already visible in the permanent settlements following the Neolithic revolution, especially as these settlements created (hierarchically) organised communities and the development of duties and tasks towards the community. ${ }^{17}$ Another noticeable stage concerns the city-states or the polis of ancient Greece, which had clearly defined, and restricted citizenship, with noticeable differences between Sparta and Athene in terms of the distribution of that citizenship. As the Roman empire had an altogether different size again, this had implications not only for the multi-ethnicity of its citizenship but also, relatedly, for the need for the notion of citizenship to be unifying. ${ }^{18}$

Since the state-in social science lingo often 'the nation-state' - is still the central reference point for discussions about citizenship, it is relevant to look into the history of state formation, more particularly the transition from feudalism in the Middle Ages to the modern nation-state. ${ }^{19}$ Typical for feudalism was the lack of centralized power, notwithstanding the pyramid structure that feudalism entailed. The land one obtained in lieu for fealty was rather conceived as private property, and the basis for the exercise of full powers. Furthermore, these lands were not connected to a particular national identity, and the lord-vassal structure was not determined by ethnicity.

The transition to the modern state required (1) the determination and recognition of precise boundaries, and the related identification of bounded territories, (2) sufficient centralization of these territories, reflected in centralized institutions, (3) combined with a sense of nationhood, a sense that the people living in that territory form a community. Two particular wars between the 14th and 17th century were especially 'formative' in relation to the emergence of states as bounded territories, wielding sovereignty over these territories, and the emergence of a sense of nationhood. ${ }^{20}$ The Hundred Years War between France and England 1337-1453 gave rise to conceptions of the respective nation-hoods, and planted the seeds of what later would develop into nationalism. The 30 Years War resulted in the adoption of the watershed treaty on the Peace of Westphalia 1648, which basically codified the system of statehood as we know it today, ${ }^{21}$ heralding a state centric world order, composed of territorially based sovereign states. ${ }^{22}$ As Brubaker highlighted, with the Peace of Westphalia the earth surface was divided into a set of mutually exclusive,

\footnotetext{
17 Scarre (2005), p. 186; Gebel (2002), pp. 313-224. Interestingly, the first settlements following this Neolithic revolution occurred in South West Asia already 11000 BC, while in Europe only around 6500 BC.

18 See also infra on the interrelation between the definition of citizenship and the ensuing rights: Roman citizenship was much thinner, in the sense that it yielded less entitlements, and protections (mostly a judicial safeguard and the rule of law).

19 See also Diener (2017), pp. 37-45; Habib (1975), p. 15; Wimmer and Feinstein (2010).

${ }^{20}$ See Rise of the Nation-State, http://blogs.spsk12.net/8576/files/2015/04/Day-.5-rise-of-nation-state s-reading.pdf (accessed September 2018).

21 The Peace of Westphalia enshrined several foundational norms of international law, more particularly states' sovereign immunity, equality of states, and the doctrine of non-intervention.

${ }^{22}$ Falk (2002) referring to the emergence of modern system of sovereign states and of a state centric world order, composed of territorially based sovereign states, pp. 311-312. See also Insin and Turner (2002), p. 6.
} 
bounded territorial jurisdictions, implying that the world's population was divided into a set of bounded and mutually exclusive citizenries and-with the emergence of the institution of 'nationality' - nationalities. ${ }^{23}$

On the basis of these foundational principles, the required centralisation took place from the 17th century onwards, and especially in the 18th and 19th century, first by absolute monarchs. ${ }^{24}$ Diener highlights in this respect that the foundations of the modern state were provided by the capacity to demarcate land and identify people as belonging to one state. ${ }^{25}$ The centralisation was further bolstered by the large scale capacity of taxation, and coercive control of their population through advanced bureaucracies. Interestingly, the control and repression that went hand in hand with this centralisation move was also used to nurture nationalism since the King proclaimed to act for the good of the nation. Put differently, through the construction of meaningful political communities, loyalty to the state was ensured and state power was consolidated. ${ }^{26}$

The idea of citizenship as reflecting loyalty, deep commitment and allegiance was thus clearly visible in relation to the emerging nation-state. Through the 17 th-19th centuries a shift took place from loyalty to the King, to loyalty to the political community, the nation, especially with the rise of popular sovereignty (democracy). ${ }^{27}$ The 18th century enlightenment and the growing emphasis on rights, and particularly equality and equal rights, further shaped thinking in terms of citizenship as referring to equal citizens, as citizens entitled to equal rights. ${ }^{28}$

Actual nationality laws were codified for the first time in the early 19 th century. ${ }^{29}$ The creation of the institution of nationality was triggered by the need to define one's own, when states were recognized as bounded territories with sovereign powers in their respective territories and international law identified state responsibilities in relation to 'one's own'. States' limited resources make it indeed increasingly important that persons are allocated to a particular territory and state, so that closure can be exercised in relation to the 'others' - particularly the poor 'others', ${ }^{30}$ and the control of the flow of persons across state borders is ensured. ${ }^{31}$

\footnotetext{
${ }^{23}$ Brubaker (1992), p. 22.

${ }^{24}$ This centralization was first realized by Spain, then by the UK and France.

${ }^{25}$ Diener (2017), p. 44.

${ }^{26}$ See also Habib (1975), p. 15. See also Barkey and Parikh (1991), p. 530: 'The state gained power over the population through coercion but was then able to gain their consent as well by making them citizens entitled to certain rights from the state'.

27 Wimmer and Feinstein (2010) discuss this development as self-rule in the name of a nation of equal citizens, p. 764.

${ }^{28}$ The American and French revolutions linked notions of popular sovereignty and fundamental rights, thus giving substance to the institution of citizenship: see also Brubaker (1992), pp. 36-39.

${ }^{29}$ Brubaker (1992), pp. 35 et seq.

${ }^{30}$ See also Brubaker (1992), p. 181. Interestingly this closure against migrant poor was already visible in 15th-16th century Germany but then at the level of the cities, at a time when the municipalities had high degree of autonomy and thus power (Brubaker (1992), pp. 64-65, 68: the responsibility for the poor only shifting to the state of Germany in the 19th century).

${ }^{31}$ Brubaker (1992), pp. 25-27.
} 


\subsubsection{Changing Spatiality of Citizenship: On-Going Developments}

Until today the central reference point of citizenship, the most relevant 'political community', remains the (nation-)state, but it is obvious that various on-going developments imply a re-alignment of citizenship. Traditionally, the state represented the key institutional order, also because it had a central role in the facilitation and regulation of the industrial, educational and cultural sector. ${ }^{32}$ However, in the meantime the lives of people are increasingly determined by policies and practices that are not set by the state. The manifold developments in this respect have also triggered reconceptualisations of citizenship. Two developments are highlighted here.

Firstly, powers that were traditionally held by states have been shifted towards regional and local governments (decentralisation) and towards international organisations (supranationalism). The resulting multi-level governance has gone hand in hand with the recognition of multiple, intersecting memberships. ${ }^{33}$ EU citizenship is particularly noteworthy in this respect. While EU citizenship is attached to national citizenship of one of the Member States, and these states in principle retain virtual complete freedom (see below) to decide the requirements for acquisition, the status of EU citizenship has increased the interdependence of nationality policies of the Member States. ${ }^{34}$ Furthermore, whereas EU citizenship aims to construct a European identity, and can thus been seen to undermine the link between nationality/ citizenship on the one hand and the traditional nation-state on the other ${ }^{35} \mathrm{EU}$ citizenship's residence rights do facilitate naturalisation in the Member State of residence ${ }^{36}$ Finally, and as will be argued more fully below, several key rights of EU citizens point to the crucial importance of residence and voting rights for the effective realisation of membership, more particularly the right to enter and reside, and the right to vote (in local and European elections). ${ }^{37}$

Secondly, the changes of the international order towards 'global governance' has resulted in the recognition of the growing role of non-state actors (not only various types of international organisations ${ }^{38}$ but also transnational corporations, NGO's etc.), and their actual impact on the lives of people. These changes are further

\footnotetext{
${ }^{32}$ Sassen (2002), p. 279.

${ }^{33}$ Bauböck and Giraudon (2009), p. 448. See also McMahon (2012), pp. 7-8.

${ }^{34}$ Kochenov (2010), p. 2. See also Oosterom-Stapels (2018) in this special issue.

${ }^{35}$ Rostek and Davies (2006), pp. 5-6.

${ }^{36}$ Kochenov (2010), p. 3.

${ }^{37}$ Kochenov (2011) on the case law of the Court of Justice of the European Union (CJEU) on EU citizenship rights referring to the cases of Rottmann (Case C-135/08, ECLI:EU:C:2010:104), Ruiz Zambrano (Case C-34/09, ECLI:EU:C:2011:124) and McCarthy (Case C-434/09, ECLI:EU:C:2011:277), and the extent to which it recognizes EU citizenship rights also when no border has been crossed, can be argued to rethink the boundaries of the community and thus also the nature of the community. EU citizenship is arguably less centrally concerned with free movement rights and economic integration but rather with the recognition of the central importance of fundamental rights, p. 55.

${ }^{38}$ For an elaborate review of the enormous range of 'international organisations' and their position, and role, see Klabbers (2015).
} 
eroding the position of the state as reference point for membership, for "citizenship', ${ }^{39}$ triggering arguments about post-national, and cosmopolitan citizenship. ${ }^{40}$

In the end, and notwithstanding the recognition that governance is performed at many levels, ${ }^{41}$ it remains justified to dedicate a special issue to nationality, referring to the legal bond between an individual and the state/nation-state, since nationality can still be considered the master status. ${ }^{42}$ As the following discussion on the rights that are contingent on nationality will reveal, nationality comes with core membership rights (rights to enter and reside, voting rights), that form the requisite basis for the effective enjoyment of (other) fundamental rights.

\subsection{Membership: Rationale, Criteria and Contours of the Political Community}

Turning to the second element of the definition of citizenship, namely 'membership', citizenship is supposed to reflect a special bond with the political community concerned, one that makes the person possessing it deserving of the rights, and entitlements contingent on membership. There is indeed a close interrelation between the nature of the community, the criteria for membership and the rights contingent on membership: the one informs the other, while the latter confirms the former and vice versa. At the highest level of abstraction, membership of a political community requires and presupposes a certain commitment, loyalty, or allegiance. ${ }^{43}$

Nevertheless, the shifts in spatiality of the political community, go hand in hand with shifts in the nature of the community-noted above-and entail different markers that are considered relevant as proxy for this (assumed) commitment and loyalty. The earliest versions of citizenship were not based on kinship (ethnicity), rather they were residence based, and the related consent to be bound by the same rules. This was clearly visible in the permanent settlements that emerged after the Neolithic revolution. Similarly, the early city-states of ancient Greece were not about kinship, rather about men subject to the same rules, and rights and duties of political participation. During the time of the Roman Empire, Roman citizenship was not ethnic based either, but aimed at building loyalty throughout the empire that was per definition multi-ethnic. ${ }^{44}$ During the Middle Ages, feudalism was decidedly not about an overarching community, let alone in the ethnic sense, but about fragmented, reciprocal personal relationships tied to land, and thus to the place where one lived. The subsequent centralization of power by the absolute monarchs, made people born in the territory into 'subjects of the monarch'. ${ }^{45}$ As was highlighted above, over time the Kings wanted to strengthen the loyalty of their subjects by justifying their actions

\footnotetext{
39 Benhabib (2005), p. 673. See also Habermas (2000), who refers to the 'crisis of territorially circumscribed nation-state formation', p. 447.

40 See also Sassen (2002), p. 280; Benhabib (2005), p. 675.

41 Rubenstein (2007), p. 102; Smith (2002), p. 113: 'the idea of citizenship will increasingly be severed

[...] from membership in some single, titular sovereign political community'.

42 Joppke (2007), pp. 37-38.

43 Rubenstein (2007), p. 102. See also Saffran (1997), p. 323.

44 See also Diener (2017), p. 38.

45 See Honohan and Rougier (2018) in this special issue.
} 
as being for the good of the nation, thus again invoking the sense of an overarching community. The following democratization wave implied a further shift from subjects of a monarch to citizens of a self-governing nation. It is exactly in relation to the emerging nation-states that different visions about what holds the nation together have been developed. It is here that the often referred to distinction between ethnic and civic nationalism finds its place.

\section{Citizenship as Membership in a Nation-State: Legal and Substantive Citizenship}

Since the state, 'the nation-state', is still the central reference point for discussions about citizenship, the obvious relation to 'nationalism', national identity and nationhood needs to be acknowledged. ${ }^{46}$ Indeed, citizenship has been argued to be bound up with nationhood and national identity. ${ }^{47}$ Importantly, the definition of 'a nation' is a question of choice, of 'public narratives': a nation can be defined on an ethnic ethnographic basis but also on a more inclusive, open, voluntarist basis. ${ }^{48}$ Whereas an ethnic nation is defined by common language, culture and traditions and is rather ascribed, a civic nation is constituted by all those who subscribe to a political creed and consent to be bound by the same rules of conduct and principles. ${ }^{49}$ In the latter sense, the state, membership of the state, the common citizenship, creates the nation, whereas in the former sense the pre-existing nation creates the state. ${ }^{50}$

Similarly, in relation to the state as reference point different theories of citizenship have been developed, reflecting different visions of the state, and of the community making up the state. Speaking to the interrelation between the underlying rational of citizenship, the vision of the community making up the state and conditions for acquiring citizenship, these different theories translate in differences regarding modes of acquiring citizenship, as is particularly visible in naturalization requirements. ${ }^{51}$ Relatedly, these different theories of citizenship also translate in different approaches to optimizing the integration of migrants. Theories often distinguished in this respect include communitarian, republican and liberal theories. ${ }^{52}$ As communitarian theories see the state as a community of character, the emphasis is more on sameness (and assimilation), whereas liberal theories focus more on the protection of the individual, thus leaving more scope for different ethnic identities as long

\footnotetext{
46 Orgad (2017), p. 345.

47 Brubaker (1992), p 182.

48 Brubaker (2004), pp. 117, 123. See also Miller (1995) where he points out that a nation's distinctive character can be to encompass a diversity of ethnic groups and Anderson (2017) who sees nations as imagined communities.

49 Orgad (2017), pp. 345-346.

${ }^{50}$ Ignatieff (1987).

51 See Orgad (2017), pp. 344-345.

52 See also Honohan (2017).
} 
as there is a commitment to liberal values and institutions. ${ }^{53}$ A republican theory on citizenship is all about active citizenship and participation in public life, and thus screens applicants for naturalization on their civic virtues, loyalty to constitution and integration efforts. $^{54}$

When analysing citizenship as referring to the special bond between a citizen and a nation-state, different dimensions of citizenship have been distinguished. Citizenship as full (and equal) membership of the state, ${ }^{55}$ is further subdivided in citizenship as legal status on the one hand and citizenship as socio-political membership on the other. Put differently, in addition to legal citizenship (or nationality), referring to the legal bond between an individual and a state, also a more substantive citizenship can be identified. ${ }^{56}$ The legal status dimension triggers questions about criteria and procedures of acquisition of legal citizenship or nationality. ${ }^{57}$ Substantive citizenship not only encompasses the rights and duties contingent on (legal) citizenship, but also refers to questions of participation, identity and belonging. ${ }^{58}$ Whereas different authors identify slightly different dimensions, ${ }^{59}$ there are clearly recurring themes, as well as an acknowledgement that these dimensions are interrelated. ${ }^{60}$ While rights, equal rights, are an essential attribute of citizenship, this special membership is not only a matter of taking part (politically and otherwise), but also of creating a collective identity and feeling part (belonging). ${ }^{61}$

\footnotetext{
53 Honohan (2017), p. 90; Gans (2017), p. 116. Orgad (2017) correctly distinguishes between two types of liberalism. One concerns liberalism as modus vivendi, allowing plural ways of life as long as one is committed to obey the laws and to peaceful coexistence. The other considers liberalism as an ethical project and also require a commitment to liberal values and institutions (muscular liberalism), pp. 344-345.

${ }^{54}$ Bauböck (2010), p. 852.

${ }_{55}$ Rubenstein (2004), p. 27.

${ }^{56}$ Citizenship has been described as 'a collection of rights, duties and opportunities for participation that define the extent of socio-political membership' (Rubenstein and Adler (2000), p. 522).

${ }^{57}$ Brubaker (1992), p. 21. See infra and see Honohan and Rougier (2018) and De Groot and Vonk (2018) in this special issue.

${ }^{58}$ In terms of citizenship and boundaries: citizenship identifies both legal boundaries (status/rights), and social boundaries (identity and belonging).

${ }^{59}$ Contra Goodman (2014), critical about using citizenship as a catch all phrase for describing and rights, and status and identity, p. 19.

${ }^{60}$ See also the introduction by Shaw and Stiks (2013) in the volume they edited on Citizenship Rights in which they refer to Joppke (status, rights, identity), Wiener (access, rights, belonging), Bauböck (practices, rights and membership), Bellamy (participation, rights, belonging) and Benhabib (collective identity, social rights, political membership). Bloemraad (2017) distinguishes between status/access, rights, participation, identity/belonging. Her account focuses strongly on bounded territory-state control over resources-equal access to right, p. 525.

${ }^{61}$ See also Bloemraad et al. (2008), p. 154.
} 


\section{Nationality: The Legal Bond Between an Individual and a State}

Without denying the importance of various ongoing controversies about the dimensions of belonging and identity, ${ }^{62}$ this special issue of the Netherlands International Law Review will, obviously, focus on the legal facets of citizenship. The remainder of this introductory article will provide the overarching framework for the articles of this special issue, ${ }^{63}$ introducing the themes developed by them, where relevant including explicit cross references. Throughout, the interrelations between the various discussion points are highlighted. This contribution furthermore supplements the other articles with an explicit discussion of the shifts in rights that are contingent on nationality, while underscoring the central importance of citizenship as a status that guarantees equal rights for all citizens. ${ }^{64}$

Several pressing questions arise in relation to nationality, as referring to the legal bond between an individual and the state. ${ }^{65}$ This part will address several of these, often interwoven, questions. Questions about the meaning/rational of this special membership and the related delimitation of membership (4.1) are closely interwoven with the identification of the effects of this status. The (shifts regarding the) rights (including entitlements and protection mechanisms) (4.2) determine the importance of this status, and thus also the relevance of the fight against statelessness (4.3) and the acceptability of deprivations of nationality. All of the above considerations inform the debate about the acceptability of dual (multiple) nationality (4.4).

As was highlighted above, the emergence of nationality as legal status happened at the intersection of various developments in the 17th-18th century: the emergence of the nation-state, the division of the earth surface into a set of mutually exclusive territorial jurisdictions, each of which sovereign within its territory, and the development of the administrative capacity to demarcate land and identify people as belonging to a state. ${ }^{66}$ All of the states thus demarcated have a vital interest in controlling migration across one's borders, and thus also to determine who belongs to the nation. ${ }^{67}$ In the words of

\footnotetext{
62 See in this respect the broader debates on how to turn migrants into members (inter alia, Baldi and Goodman (2015)), and relatedly the different types of membership and engagement that a sate seeks (Goodman (2014), distinguishing between national and state identity). In this regard, it is interesting to notice that integration requirements often feature as prerequisites for obtaining nationality (through naturalisation) while nationality is argued to increase political and civic engagement, which in turn would strengthen the identification with the national community, and social integration (Bloemraad (2017), p. 544).

63 For further information on the articles contained in this special issue, and the order in which they feature, see the explanation at the end of this contribution.

64 See also Rubenstein (2004), pp. 5-6. Bloemraad (2017) correctly highlights the reality of society discrimination that undermines the promise of equal rights, p. 537.

65 This special issue is indeed concerned with the nationality of natural, not legal, persons.

66 Brubaker (1992), p. 22.

${ }^{67}$ Goodman (2014) identifies as reasons why states emphasize their sovereignty in determining who are its nationals because of the importance of resource allocation, and the goal of social cohesion, loyalty and solidarity, pp. 22-25.
} 
Brubaker 'the principle and the administrative apparatus of closure are essential to the modern state and its project of territorial rule'. ${ }^{6}$

\subsection{Acquisition of Nationality}

When discussing what determines the contours of the community, the in-out criteria, in relation to the nation-state, the notion of nation needs to be considered, more particularly: What defines a nation? What holds it together? ${ }^{69}$ The discussion of membership of a political community above has already noted that when states set out to define 'their own', their nationals, one way or the other they seek to identify those with an attachment to the state, a certain commitment, loyalty, to the territory and/or its people. ${ }^{70}$ In its famous Nottebohm judgment ${ }^{71}$ the International Court of Justice (ICJ) has emphasized the relevance of an effective or genuine link between an individual and a state to justify a conferral of nationality on the individual concerned that needs to be respected by other states. ${ }^{72}$ According to Crawford: 'the decision in Nottebohm is a reflection of a fundamental concept long present in the materials concerning nationality on the international plane' ${ }^{73}$ There are indeed ample antecedents in continental literature and decisions of national courts. ${ }^{74}$

When reflecting on the proxies that can be used to measure this link, this attachment, one needs to think further about the type of bond nationality is supposed to capture. It has been argued that being a citizen of a state is having a stake in the country, ${ }^{75}$ so that one's well-being is bound with the well-being of the state. ${ }^{76}$ Markers that have been suggested in this respect include habitual residence, having the center of ones interests and family ties in the state concerned. ${ }^{77}$ Arguably, having a stake in a state is also related to the special rights and protection mechanisms one is entitled to as national of that state, ${ }^{78}$ since this entails that one's interests are profoundly affected by the institutions of that state. ${ }^{79}$ Crawford posits that the "effective link' requirement can be satisfied through residence requirements and membership of ethnic groups associated with the state territory. ${ }^{80}$ This in turn can be related to the various ways in which the nation can be conceived, as an ethnic nation or a civic

\footnotetext{
68 Brubaker (1992), p. 24.

69 See also Anderson (2017).

70 Brubaker (1992), pp. 88-92, 122-124.

71 Nottebohm (Liechtenstein v. Guatemala), Judgment, ICJ Reports 1955, p. 4.

72 It needs to be acknowledged that some authors seek to nuance the implications of Nottebohm, as being specific to the case of dual nationals (Leigh (1971), p. 468).

73 Crawford (2012), p. 513.

74 See also Basdevant (1909), p. 59; German nationality (1952) 19 ILR 319.

75 See also Bauböck (2009) on 'External Citizenship'; Tanasoca (2015), p. 40.

76 Crawford (2012) highlights in this respect that when the UN Convention on the Reduction of Statelessness of 1961 obliges states to reduce statelessness, it relies on 'various criteria of factual connection and evidence of allegiance', p. 517.

77 Nottebohm (Liechtenstein v. Guatemala), Judgment, ICJ Reports 1955, p. 4, at 22.

78 See also de Groot (2015), p. 29.

79 Tanasoca (2015), p. 40.

${ }^{80}$ Crawford (2012), p. 514.
} 
nation: as a nation built on kinship, or a nation uniting around a common political creed and values. ${ }^{81}$

It is often emphasized that policing the boundaries of the community making up the state, and thus the criteria and procedures that need to be fulfilled to obtain access to nationality, are one of the last vestiges of state sovereignty. ${ }^{82}$ It is, however, difficult to deny that increasingly international law also identifies constraints on states' discretion in this regard. First, the ICJ's Nottebohm judgment already indicated that states cannot grant nationality without proper basis, ${ }^{83}$ in that the conferral of nationality needs to reflect a genuine attachment or link. The latter requirement remains topical, as is visible, inter alia, in relation to the controversies surrounding the conferral of nationality to gifted athletes, aimed at more 'national' success in the Olympics. ${ }^{84}$ Similarly, the prohibition of compulsory change of nationality/naturalisation, collective naturalization, ${ }^{85}$ and extraterritorial naturalisation ${ }^{86}$ can be related to this 'effective link' requirement. ${ }^{87}$

Secondly, and as will be discussed at more length below, the recognition of the individual right to a nationality, and the related norms aimed at countering statelessness, ${ }^{88}$ also exert pressure on states to confer nationality on particular individuals (that would otherwise be stateless). Thirdly, and in line with the central importance of the equality principle in international law, international courts have become increasingly critical of instances of racial discrimination in relation to the definition and application of criteria for the acquisition of nationality (at birth). ${ }^{89}$ The African Commission on Human and Peoples' Rights (ACHPR) established a violation of the African Charter on Human and Peoples Rights (African Charter) because the new nationality law of Côte d'Ivoire retroactively stripped a particular ethnic group of its nationality, notwithstanding its long-standing ties with the state. The

\footnotetext{
81 These different conceptions of the nation can be related to the different logic of inclusion in the state that Goodman identifies: a logic of sameness (state identity referring to kinship) versus a logic of togetherness (state identity rather referring to solidarity, common plans etc.): Goodman (2014), pp. 2, 27-30.

82 Orgad (2017), p. 345. See also Wimmer (2009), pp. 257-258.

83 According to Crawford the related manipulations of the law of nationality, would amount to internationally wrongful conduct; Crawford (2012), p. 520.

84 For a more detailed account, see Wollmann (2018) in this special issue.

85 In re Rau (1930) 6 ILR 251.

86 Extraterritorial naturalisation has been described as 'granting of citizenship to persons living in another country who share certain characteristics (e.g. in ethnic, religious or linguistic terms)'. For a detailed analysis, see Traunmuller (2013). See also Bolzano Recommendations on National Minorities and Inter-State Relations, OSCE HCNM (2008), Principle 11: 'States may take preferred linguistic competences and cultural, historical or familial ties into account in their decision to grant citizenship to individuals abroad. States should, however, ensure that such a conferral of citizenship respects the principles of friendly, including good neighbourly, relations and territorial sovereignty, and should refrain from conferring citizenship en masse...'. The Explanatory Note links this recommendation to the Nottebohm case and its requirement of 'the existence of a genuine link' between the state and the individual upon whom citizenship is conferred: Bolzano Recommendations on National Minorities and Inter-State Relations, OSCE HCNM (2008), p. 19.

87 Crawford (2012), pp. 523-524.

${ }^{88}$ See also van Waas and Jaghai (2018), and Honohan and Rougier (2018) in this special issue.

89 Spiro (2011), pp. 721-722.
} 
Commission highlighted that the ethnic group concerned has an undisputable valid claim to Ivorian nationality because they had become 'integral and definitive part of the formation of the Ivorian ethno-cultural landscape'. ${ }^{90}$ Similarly, in the Yean and Bosico case ${ }^{91}$ the Inter-American Court of Human Rights (IACrtHR) did not accept the manipulation of the nationality law in the Dominican Republic which had the effect of impeding the acquisition of Dominican nationality by children of Haitian origin. $^{92}$

Nationality is primarily acquired at birth, so as to optimize legal certainty, but can also be the result of naturalization, thus enabling migrants that come and settle in a state to obtain the nationality of that state. Birth right citizenship is bestowed on persons automatically, and is not a matter of choice. Interestingly, the criteria developed for this birth right citizenship are considered to be proxies for characteristics that reflect long term loyalty and affiliation with the polity. ${ }^{93}$ Put differently, the persons that acquire citizenship as a birth right are assumed to be committed and loyal to the state concerned. Naturalisation requirements may differ from state to state, typically these requirements include a certain period of residence, knowledge of the language and the country, and an oath of loyalty. Several of these explicit requirements can be seen to measure attachment to the country, and solidarity. ${ }^{94}$ In this respect naturalization requirements and procedures can be seen to aim at forging the connection between the newcomer and the polity, seeking explicit consent to be bound by rules of the community and proof of loyalty (what is assumed at birth) ${ }^{95}$ Authors that have advocated alternative criteria to acquire citizenship similarly focus on criteria that reflect social attachment, and social membership. ${ }^{96}$

As is further elaborated upon in the contribution of de Groot and Vonk in this special issue, traditionally two systems of birth right citizenship have been distinguished, ius soli (based on the place of birth) and ius sanguinis (based on descent). Ius soli systems see citizenry as a territorial community, which can be related to the feudal idea that those who were born on the territory where subject to the rule of that territory. ${ }^{97}$ The underlying idea of community is also more future oriented, in the sense that people born on a territory are intended to stay there and develop ties and commitment to the community living on that territory. ${ }^{98}$ This is exactly the

\footnotetext{
90 The discriminatory deprivation of nationality was held to constitute a violation of Art. 5 African Charter: OSI v. Cote D' Ivoire (2016) Communication 318/06 ACHPR, para. 104.

91 IACrtHR Girls Yean and Bosico v. Dominican Republic (2005), Series C No. 130.

92 See also Kesby (2012), p. 55.

93 Rodriguez (2009).

94 Orgad (2017), p. 341.

95 Bauböck et al. (2006), pp. 449-450. See also Kostakopoulou (2003), p. 88, and Orgad (2017), p. 341: it is about proving that you are worthy.

96 See, inter alia, Shachar (2009) who advocates in her book Birthright Lottery for a ius nexi: citizenship by genuine connection to the country, which focuses on social membership as gate to political/legal membership; and Spiro (2011), p. 721 who calls for a presumption in favour of nationality on the basis of habitual residence.

97 Bauböck (2015), p. 6.

98 See also Brubaker (1992), p. 123
} 
reason why settler states opted for ius soli. ${ }^{99}$ Ius sanguinis systems see citizenry rather as a community of descent, which builds on the assumption that kinship guarantees commitment, allegiance and loyalty. ${ }^{100}$ Whereas ius sanguinis is the system that is most widely used throughout the world, ${ }^{101}$ increasingly it is complemented by ius soli elements, so as to attempt to include migrants in national community. ${ }^{102}$

In regard to the naturalisation requirements, the question is always whether the requirements are high enough, so as to make sure that persons acquiring nationality have the requisite attachment and loyalty, without being too high. In the latter regard, political theory about the just society emphasize that long-term residents should have the opportunity to become full members of the polity. ${ }^{103}$ It has been noted that there is a pendulum back and forth in terms of requirements for migrant naturalisation, a movement to facilitate naturalisation is followed by sharpening requirements again, more particularly because of concerns about failing integration and cohesion. ${ }^{104}$ The question of dual nationality also comes up here as states can require as precondition for naturalisation that one relinquishes one's existing nationality. ${ }^{105}$

\subsection{Rights and Obligations Contingent on Nationality}

This part will mainly discuss the developments that have taken place in terms of rights that are contingent on nationality. While important shifts have taken place in this respect, in that more and more rights have been detached from nationality, the following analysis will demonstrate that the rights that are key to membership in the state are still reserved for nationals. This speaks to the on-going importance of having a nationality and a right to nationality as well as the fight against statelessness. Underscoring the centrality of equality among citizens, and the intrinsic link between citizenship and equal rights, is the case law of international courts that become ever more critical about differentiations in terms of rights between birth right and naturalized citizens. ${ }^{106}$ It is in any event important to contrast the promise of equal rights that citizenship holds with the reality of often deep-seated discrimination and marginalisation of particular groups of citizens. ${ }^{107}$

\footnotetext{
99 Saffran (1997), p. 314.

100 Brubaker (1992), p. 123.

101 For further information see Honohan and Rougier (2018) in this special issue.

102 De Schutter and Ypi (2015), p. 240. However, the increasing integration concerns with third and fourth generation of migrants does lead to more demanding civic integration and related naturalization requirements: Joppke (2007), pp. 39-41.

103 De Schutter and Ypi (2015), p. 238.

104 Joppke (2007), pp. 43-44; Baldi and Goodman (2015), pp. 1154-1155.

105 See Wautelet (2018) in this special issue.

106 Inter alia, European Court of Human Rights (ECtHR) Biao v. Denmark, Application no. 38,590/10, 24 May 2016; ACHPR, Modise v. Botswana, Communications 97/93, 6 November 2000; ACHPR, Open Society Justice initiative v. Cote d'Ivoire, Communications 318/06, 27 May 2016, paras. 99-104.

107 The Roma are a prime example in this respect: Vermeersch (2014), pp. 481-482.
} 
When considering the obligations that used to be reserved for nationals, some of them have been made generally applicable to residents (the duty to pay taxes), or even more broadly to everyone in the jurisdiction of the state (obeying laws). The transition in most countries to professional armies has eliminated military duties. It may be so that states are said to have legitimate expectations of loyalty of their citizens, international law recognizes no such obligation. ${ }^{108}$ Admittedly, several countries require an oath of loyalty or allegiance from persons seeking to naturalise, ${ }^{109}$ but this does not tend to translate into concrete obligations. ${ }^{110}$

\subsubsection{Rights, Entitlements and Protection Mechanisms (Traditionally) Reserved for Nationals}

Nationality is in several respects an important marker for international law purposes. Indeed, nationality not only determines enemy status in times of war, but states are also entitled to exercise diplomatic protection in favour of their nationals and refuse extradition of their own nationals. Since the 19th century the rule of diplomatic protection $^{111}$ was established following which one state may invoke the responsibility of a third state for an internationally wrongful act inflicted on its nationals. As diplomatic protection is conceived as a right of a state against another state, in the sense that the internationally wrongful act against the person can be constructed as an injury to the state itself, there needs to be a sufficient connection between the state exercising diplomatic protection and the individual. Nationality is supposed to reflect (guarantee) such a sufficient connection, or-referring to the ICJ in the Nottebohm case-a genuine link. In its 2006 Draft Articles on Diplomatic Protection the International Law Commission (ILC) still clearly demands sufficient ties between the individual and the state, but also acknowledges the impact of globalisation and the growing migration streams. ${ }^{112}$

Traditionally, diplomatic protection is conceived as a right of a state that does not go hand in hand with a duty towards the national disadvantaged by the internationally wrongful act. ${ }^{113}$ As these internationally wrongful acts will largely correspond to the norms found in the principal human rights treaties, ${ }^{114}$ the growing individual complaints rights before international courts (including treaty bodies) do reduce the importance of diplomatic protection. ${ }^{115}$ Nevertheless, in the several instances

\footnotetext{
108 Boll (2005), pp. 41, 46.

109 Boll (2005), pp. 58-59.

110 See however the grounds for deprivation of nationality, some of which apply even if this would cause statelessness, Art. 8(3) of the Convention on the Reduction of Statelessness (1961).

111 For a more comprehensive account of diplomatic protection, see Denza (2018) in this special issue.

112 Draft Articles on Diplomatic Protection the International Law Commission (2006) p. 8. A state can also exercise diplomatic protection in relation to recognized refugees and stateless persons as long as they are lawfully and habitually resident on its territory (tho Pesch (2015), p. 56).

113 The Mavrommatis Palestine Concessions (Greece v. Britain), 1924 PCIJ, Series A, No. 2.

114 Dugard (2009), tho Pesch (2015), p. 65.

115 See also Denza (2018) in this special issue; Dugard (2013), p. 3.
} 
where these international human rights are not respected and cannot effectively be enforced, diplomatic protection provides a possible safety net. ${ }^{116}$

Particularly important, since it also constitutes the bridge to rights and entitlements within the state, is the states duty to allow their nationals entry in the state territory. ${ }^{117}$ As the preceding historical account (on state formation) highlighted, from the moment states had clearly defined borders, and sovereign powers within these borders, questions of border control and immigration control became closely intertwined with states' quest to secure their sovereignty. ${ }^{118}$ The right to enter a state, and the protection against being expelled, implies a right to stay, and thus a right to reside. This right to stay and the 'lawful residence' that goes along with it, was traditionally also a prerequisite for the enjoyment of social rights (rights to work, social services, health care, education, and social security). ${ }^{119}$ Active and passive voting rights are also traditionally limited to citizens, to persons with the nationality of the state concerned. ${ }^{120}$ This is clearly reflected in the framing of Article 25 of the UN Covenant on Civil and Political Rights, which restricts the scope of application of voting rights and even of the right 'to take part in the conduct of public affairs' more generally to 'every citizen', as opposed to 'everyone'.

\subsubsection{Rights are Increasingly Detached from 'Nationality'}

It is widely recognized that the developing human rights paradigm increasingly constrains state sovereignty. Particularly important in relation to a special issue on nationality is the fact that human rights are rights one has simply because one is a human being, irrespective of characteristics and generally also irrespective of legal status. ${ }^{121}$ The equality principle is thus ingrained in the concept of human rights itself, as it is in relation to rights of citizens. ${ }^{122}$

The growing list of positive obligations on states to ensure the effective protection of fundamental rights, could be argued to point to some level of obligation on states to protect their nationals when they suffer severe human rights violations at the hand of third states, such as in the case of the violation of peremptory norms. ${ }^{123}$ Notwithstanding the growing support that is noted for the recognition of some duty to afford

\footnotetext{
116 As Vermeer-Künzli (2007) underscores: in the end diplomatic protection is about the optimal protection of individuals against violations of international human rights, p. 37.

117 Rubenstein and Adler (2000), p. 525. See also Kesby (2012), p. 60.

118 See also Kesby (2012), p. 101.

119 An appendix to the European Social Charter both in its original and revised version expressly restricts the personal scope of application of most Charter rights to foreigners who reside and/or work legally on the territory of the state concerned. For an extensive discussion see O'Cinneide (2014), pp. 288-289. See also Art. 8 of the Declaration on the Human Rights of Individuals Who are not Nationals of the Country in which They Live (195) A/RES/40/144.

120 See also Cole (2003), p. 370.

121 See also Habermas (2000) who claims that the international human rights system is an emerging form of citizenship beyond the state.

122 See also Rubenstein and Adler (2000) who see citizenship as the expansion of equality among citizens.

123 Dugard (2013), p. 8.
} 
diplomatic protection to nationals subjected to serious human rights violations, ${ }^{124}$ in the end the ILC Draft Articles on Diplomatic Protection stopped at pronouncing a 'recommendation to states to give due consideration to the possibility of exercising diplomatic protection, especially when a significant injury has occurred'. ${ }^{125}$ Admittedly, in so far as national standards recognize a state duty to exercise diplomatic protection, this goes hand in hand with extensive discretion. ${ }^{126}$

In regard to social rights, several developments in the jurisprudence of international courts are noteworthy. As it would be beyond the confines of this article to provide a comprehensive overview of this case law, merely two are highlighted. First, the European Committee on Social Rights has adopted an interpretation of the European Social Charter that increasingly—on human dignity grounds-counters the exclusion of illegal residents from the scope of application of the Social Charter, thus extending social rights even to illegal foreigners. ${ }^{127}$ Secondly, EU citizens' free movement rights, entail not only the rights to enter and reside in the other EU Member States, ${ }^{128}$ but also ever-expanding social rights. ${ }^{129}$

Also in regard to voting rights, there is an increasing call to extend voting rights to foreign residents. These arguments are less in terms of human rights, since human rights standards themselves are limited to "citizens', ${ }^{130}$ but rather in terms of democratic theory. In line with the old principle 'no taxation without representation' and the more recent 'all affected principle', democratic legitimacy would require that when one is subject to obligations, one should also be allowed to take part in the decision making process of these rules. ${ }^{131}$ Similarly, voting rights are advocated for those who have a stake in the country, whose future is linked to the future of the country, who is affected by the government policies and actions. ${ }^{132}$ Extending voting rights to migrants is furthermore expected to stimulate their political participation,

\footnotetext{
124 Dugard (2009), para. 14.

125 Art. 19 of the ILC Draft Articles on Diplomatic Protection (2006). See also tho Pesch (2015), p. 58.

126 See also the South African Constitutional Court in Kaunda v. President of the Republic of South Africa, in which the Court identifies a constitutional duty to consider request to offer diplomatic protection by citizens faced by actions by third states that violate international law, and a duty to deal appropriately with these requests. The recognition of a constitutional right goes hand in hand with the conferment of considerable discretion on the state: see also Coombs (2005), p. 683.

127 See European Committee of Social Rights FIDH v. France, Application no. 14/2003, 8 September 2004; DCI v. the Netherlands, Application no. 47/2008, 20 October 2009; DCI v. Belgium, Application no. 69/2011, 23 October 2012; CEC v. the Netherlands, Application no. 990/2013, 19 July 2014; FEANTSA v. the Netherlands, Application 86/2012, 9 July 2014.

128 Arts. 5, 6 and 7 of the Citizen's Rights Directive 2004/38/EC [(2004) OJ L158/77] concerning the right to enter and the right to reside for up to or for more than 3 months.

129 It has been noted though that these social rights entitlements cannot always be effectively enjoyed: see, inter alia, Pennings and Seeleib-Kaiser (2018).

${ }^{130}$ It should be highlighted that the European Convention on Human Rights (ECHR) is not framed in terms of rights (of citizens) but rather as state obligations to organise elections that secure the 'free expression of the will of the people'. This reference to people would seem to allow for an interpretation that includes non-national residents. Strikingly there exists no case law on this question, in contrast to an extensive jurisprudence on question of voting rights for non-resident nationals. See, Art. 3 of Protocol no. 1 to the European Convention on Human Rights.

131 Beckman (2006), pp. 153-154; Groenendijk (2008), p. 5; Lenard (2015), p. 125.

132 Beckman (2006), pp. 157-160.
} 
which in turn is meant to enhance their integration. ${ }^{133}$ When considering state practice, in several countries developments can be identified to extend voting rights to migrants, but there are still considerable variations, both in terms of the level at which elections are opened to foreigners (local, regional and national), ${ }^{134}$ and in terms of the extent of the residence requirements. ${ }^{135}$

\subsubsection{Nationality and the Right to Enter and Stay: The Right to Have Rights}

Notwithstanding the developments of the human rights paradigm and the related growing detachment of rights and nationality, ${ }^{136}$ there are still rights that only persons with the nationality of a state fully enjoy, more particularly rights to enter and stay in a state, and voting rights. What is particularly striking is that these rights can be argued to constitute core rights for actual, effective membership in a political community.

First of all, rights to entry and stay (reside) are the essential precondition to become a member of the polity, understood as a political community with territorial bounds. Indeed, one needs a place where one can makes one's home, ${ }^{137}$ participate politically, and exercise one's civil, political and social rights. ${ }^{138}$ In this respect Hannah Arend's famous qualification of nationality as the right to have rights can be understood: nationality as the precondition for the effective enjoyment of fundamental rights. ${ }^{139}$ As long-term resident foreign nationals obtain stronger rights of residence, including enhanced protection from deportation, as well as related socioeconomic rights (access to employment and family reunification), the term 'denizen' was coined to reflect a status which entitled persons to many but not all rights of full citizens. ${ }^{140}$

Secondly, also (national) voting rights are often highlighted as being of crucial importance because they provide opportunities for co-determining governance. ${ }^{141}$ Bellamy highlights in this respect that political participation rights are the rights

\footnotetext{
133 Groenendijk (2008), p. 5. See also Lenard (2015), pp. 122-123 who argues that collective participation in the electoral system and the shared institutions builds social cohesion. Cf. Rostek and Davies (2006), p. 5.

134 See the discussion of the quantitative analysis in Earnest (2015), pp. 4, 7.

135 Groenendijk (2008), p. 4. See Earnest (2015), pp. 5-6 who distinguishes 5 categories.

136 Kesby (2012), p. 94.

137 Inter alia, De Groot (2015), pp. 29-30.

138 Kesby (2012), p. 52.

139 Oman (2010), p. 281. See also Shachar (2014), pp. 114-115 who highlights that our rights remain fragile when we are not member of a political community. See also Somers (2008) who highlights the primary right of recognition, inclusion and membership in both political and civil society (social and political recognition), preceding the second bundle of rights consisting of civil, political, social, cultural etc. rights, pp. 6 and 25.

140 Turner (2016), p. 679.

141 Kesby (2012) p. 58; De Groot (2015), pp. 29-30. Smith (2002) acknowledges that with the different spatialities of citizenship over time - this idea of political co-determination was not always strongly present, referring to the feudal times where it was restricted to some cities (p. 106), stronger again after the revolutions in the 18th century, whereas today there would be less focus on political activism and rather on involvement in social, economic and cultural organizations (p. 112).
} 
of rights as political rights secure equal access and recognition within its decision making and organisational structures. ${ }^{142}$ Hence, voting rights are qualified as keystone rights, as 'essential prerequisite to the enjoyment of all other rights' ${ }^{143}$ and thus essential to secure a dignified life.

\subsection{The Right to Have a Nationality and the Fight against Statelessness}

As the preceding analysis demonstrated, having a nationality still greatly matters as it is the gate to obtaining so-called keystone rights (the right to enter and reside and the right to vote), that in turn enable the effective realisation of one's civil, political, social, economic, and cultural rights. Put differently, nationality is the 'bedrock for fulfilling and protecting our otherwise abstracted human rights', ${ }^{144}$ thus providing a sense of security and belonging. ${ }^{145}$ Linking back to the historical account of the emergence of nationality: 'in a world divided among exhaustive and mutually exclusive jurisdictions of sovereign states, it is axiomatic that every person ought to have a citizenship, that every person ought to belong to one state or another'. ${ }^{146}$

Conversely, persons that are stateless tend to be described as particularly vulnerable, since 'being stateless renders one vulnerable to the non-observance of rights by state and other individuals' ${ }^{147}$ Indeed, as was pointed out by Hanna Arendt: when stateless there is no political community willing and able to guarantee one's rights. ${ }^{148}$ The severe predicament of stateless persons is also keenly understood by international human rights courts, where they equate being stateless with being deprived for all practical purposes of one's rights. ${ }^{149}$

Consequently, it is not surprising that the fight against statelessness has early roots, ${ }^{150}$ and has been relentless. The two most prominent and interrelated strategies in international law to combat statelessness are on the one hand the realisation of the right to a nationality, and on the other countering arbitrary deprivations of

\footnotetext{
142 Bellamy (2008), pp. 598-590.

143 Kesby (2012), p. 69.

144 Oman (2010), pp. 279-280. See also Shachar (2014); Brubaker (1992), p. 70.

145 Citizenship is said to have a crucial bearing on the basic goods and opportunities that shape life chances: Brubaker (1992), p. 24.

146 Brubaker (1992), p. 30.

147 Kesby (2012), p. 62. See also IACrtHR Girls Yean and Bosico v. Dominican Republic (2005), Series C No. 130.

148 Arendt (1968), pp. 175-177.

149 See also IACrtHR Advisory Opinion on Naturalisation Law Costa Rica (1984) OC-4/84, para. 34. See also the judgement of IACrtHR Girls Yean and Bosico v. Dominican Republic (2005), Series C No. 130, paras. 178-179 where the Court equates a denial of nationality with a denial of juridical personality, because it denies absolutely an individual's condition of being a subject of rights and renders him vulnerable to non-observance of this rights by the state and other individuals.

150 Brubaker notes the first concerns about combating 'statelessness' already in the 17th-18th century, in the sense that states were concerned that no one would be left homeless, without protection, without rights of residence and support (Brubaker (1992), pp. 65-66).
} 
nationality. ${ }^{151}$ The international law rules that are thus developing further limit state sovereignty regarding the acquisition and deprivation of nationality. Nevertheless, as the following overview will reveal, ample state discretion remains.

The Universal Declaration on Human Rights already enshrined a right to a nationality (for everyone), and prohibits the arbitrary deprivation of nationality. Since then the right to a nationality features in various international conventions, including the International Covenant on Civil and Political Rights (1966, ICCPR), the Convention on the Rights of the Child (1989, CRC), the International Convention on the Elimination of Racial Discrimination (1969, CERD) and the Convention on the Elimination of All Forms of Discrimination against Women (1979, CEDAW), the latter two conventions confirming the central importance of the prohibition of discrimination in this respect. It should be highlighted though that these general recognitions of everyone's right to nationality does not identify on what state the responsibility lies to grant its nationality. The 1961 UN Convention on the Reduction of Statelessness and the 1997 European Convention on Nationality ${ }^{152}$ do specify that children are to acquire the nationality of the country in which they are born if they do not acquire any other nationality ${ }^{153}$ Furthermore, the latter Convention adds more generally as one of its overarching principles that 'the rules on nationality of each State Party shall be based on the following principles: everyone has the right to a nationality. ${ }^{154}$ While this is difficult to translate in concrete benchmarks, it has an undeniable signaling function. The 1997 European Convention on Nationality also gives pride of place to the prohibition of discrimination in relation to nationality questions where it stipulates that states must avoid all discrimination on grounds of sex, religion, race, colour, national or ethnic origin. ${ }^{155}$

Given the importance of nationality as anchor point for the effective enjoyment and protection of one's rights, the right to a nationality encompasses a right to retain one's nationality. Consequently, it has been long understood that international law limits states' sovereign power to deprive persons of their nationality. ${ }^{156}$ The prohibition of arbitrary deprivation of nationality already featured in the Universal Declaration on Human Rights, ${ }^{157}$ and has been further regulated in the UN 1961 Convention and the 1997 European Convention. Both conventions strictly circumscribe the situations in which states are allowed to deprive persons of their nationality. While these limitations on state sovereignty may be welcomed, it should be highlighted

\footnotetext{
151 These two strategies are interrelated since the right to a nationality implies the right of each individual to acquire, change and retain a nationality: see https://www.ohchr.org/EN/Issues/Pages/Nationalit y.aspx (accessed 11 October 2018).

152 The 2006 Council of Europe Convention on the avoidance of statelessness in relation to state succession has so far only been ratified by 3 states.

153 Arts. 1(4) and 2 of the Convention on the Reduction of Statelessness (1961); and Art. 6(2) of the European Convention on Nationality (1971).

154 Art. 4.

155 Art. 5(1).

156 Gibney (2017), pp. 359-360. See also Eritrea Ethiopia Claims Commission-Partial Award: Civilian Claims-Eritrea's Claims 15, 11, 23 and 27-32 (2004) Reports of International Arbitral Awards No. 16, pp. $195-247$.

157 Art. 15(2).
} 
that in these limited circumstances states are allowed to deprive persons from their nationality, even if it would leave them stateless. When comparing the deprivation grounds in both conventions, both contain various grounds that refer to situations in which one can seriously question the person's commitment, and loyalty to the state, such as 'conducting oneself in a manner seriously prejudicial to the vital interests of the state', and 'voluntary service in another military force'. ${ }^{158}$ The possibility to deprive nationality on such grounds has received renewed attention in the current fight against terrorism. ${ }^{159}$

The European Convention on Nationality also allows deprivation of nationality in cases where the strength of the link between the individual and the state is considered to become too weak. ${ }^{160}$ The latter of course ties in with the approach one takes to dual or multiple nationality, which is also informed by the current reality of a mobile world in which people often migrate to other countries and develop close connections with more than one state, thus multiplying the situations in which persons have or seek to have and retain multiple nationalities. ${ }^{161}$

As in relation to the acquisition of nationality, also in relation to nationality deprivation, international law increasingly identifies constraints imposed on state sovereignty by the prohibition of discrimination. ${ }^{162}$ The ongoing importance of this particular constraint is confirmed by the various tragic examples where discriminatory deprivation/denial of nationality has been meted out to minorities, making them ever more vulnerable in the process, marginalizing them. The denationalization of the Jews as component part of the plan to exterminate them during the holocaust ${ }^{163}$ is undoubtedly one of the most vicious examples. The current plight of the Muslim community in Myanmar shows how topical concerns about discriminatory deprivation of nationality remain. ${ }^{164}$

\subsection{Dual Nationality}

The approach towards dual nationality confirms and highlights the interrelation between the rationale of nationality, the special bond of membership it reflects, and conditions for acquisition and deprivation. Indeed, the demands one has regarding the degree of loyalty and commitment to the state that is supposed to underlie a bond of nationality, informs the extent to which one would accept dual or even

\footnotetext{
158 Art. 8(3) of the Convention on the Reduction of Statelessness (1961); Art. 7(c) and (d) of the European Convention on Nationality (1971).

159 See also van Waas and Jaghai (2018) in this special issue which highlights the problems involved, especially in relation to persons with double nationality.

160 Art. 7 (a)(e).

161 See also below and Wautelet (2018) in this special issue.

162 Art. 9 of the Convention on the Reduction of Statelessness (1961); and Art. 6 of the 1997 European Convention on Nationality.

163 Sands (2016), p. 166.

164 Advisory Committee on Rakhine State, Towards a Peaceful, Fair and Prosperous Future for the People of Rakhine, Final Report (2017), pp. 29-31.
} 
multiple nationalities (which is reflected in the regulation on acquisition and deprivation of nationality).

Traditionally dual nationality was considered an anomaly because the legal bond of nationality between an individual and the state was considered exclusive and indissoluble, reflecting perpetual allegiance and loyalty. ${ }^{165}$ In the meantime, and particularly since the 1980 s the conceptualisation of citizenship and nationality has changed, translating into a growing tendency to accept dual nationality. ${ }^{166}$ A variety of reasons have been identified to explain this shift, ${ }^{167}$ but what seems to play a significant role is the current reality of a mobile world, in which people migrate to other states than their state of origin and nationality. The new patterns of belonging that thus emerge facilitate the acceptance that one can have loyalties to more than one state. The expansion of communication channels furthermore makes it easier to be a functional citizen in both/more countries. ${ }^{168}$ Also strategic considerations come into play, both for the state of origin and the state of residence: the former seeks to accommodate its own nationals abroad who want to maintain ties and the latter is influenced by changing notions of what will optimize integration of migrants into the state of residence. ${ }^{169}$

As is further elaborated in the other articles in this special issue, dual nationality raises additional thorny questions in relation to the exercise of diplomatic protection, ${ }^{170}$ and whether this more open attitude towards dual nationals does not facilitate so-called instrumental citizenship (for example in the world of Olympic sports). ${ }^{171}$

\section{Some Concluding Observations}

The preceding analysis has revealed how the changing spatialities of citizenship culminated in a focus on the nation-state, and the emergence of legal citizenship or nationality, reflecting the legal bond between an individual and a state. It was also noted that in several respects the parameters of nationality keep changing. More particularly, four developments have been highlighted that circumscribe the sovereign right of states to determine who are their nationals, both legally and through de facto pressures. First, as was emphasized in this contribution, and is taken up in several other articles in this special issue, the expanding human rights paradigm does not only increasingly detach rights from nationality (status), but also constrains the sovereign choices made in relation to the conferral and deprivation of nationality, not in the least through the prohibition of discrimination. Secondly, and relatedly, the

\footnotetext{
165 Spiro (2017), pp. 622-623.

166 Sejersen (2008), p. 534.

167 Spiro (2017), pp. 622, 630; Sejersen (2008), pp. 538-542.

168 Sejersen (2008), pp. 538-539.

169 Sejersen (2008), p. 542.

170 See Denza (2018) in this special issue.

171 Spiro (2017), p. 623. See also Wollmann (2018) in this special issue.
} 
recognition of a right to a nationality, and the ensuing standards and policies aimed at ending statelessness add to these constraints. Thirdly, the development of other significant citizenships, more particularly EU citizenship, that interact with nationality, de facto pushes states towards a more harmonized approach in relation to nationality issues. Last but not least, the reality of the mobile world-characterized by rising migration-leads to pressing questions of how to optimize the inclusion of migrants (that are there to stay) as full members of the state. These migrant communities and their transnational connections challenge the traditional understanding of belonging, commitment and loyalty. This in turn affects both the way in which birthright citizenship is conceived (with systems of ius sanguinis increasingly including elements of ius soli), and the requirements for naturalisation.

At the same time, the analysis confirmed that even when the human rights paradigm increasingly detaches rights from nationality, nationality still matters, greatly, as is also confirmed by the relentless fight against statelessness and the restrictions imposed on deprivations of nationality. Indeed, nationality is still essential for the keystone rights of entry and residence that are prerequisites for the effective enjoyment of the other rights. Similarly, only nationals have full voting rights, and thus truly participate in the governance of the polity.

The parameters of nationality will continue to shift, partly in response to the current reality of a mobile world, where persons, through migration, often have special bonds with more than one state, and partly in response to intersecting citizenships linked to multi-level governance. Some of these developments are already becoming visible, such as the trend to increasingly detach voting rights from nationality. Other changes, such as those in response to the on-going migration and asylum crisis, remain to be seen.

\section{The Special Issue on Nationality and International Law}

Having provided the overarching framework for the special issue, the (other) articles making up the special issue can be briefly introduced.

Most articles are concerned with on-going developments and debates in public international law concerning nationality, and deal more particularly with questions of access to nationality (status) and deprivation of nationality, and protection mechanisms contingent on nationality. In the process, questions of how to address instrumental citizenship and dual nationality are also discussed. The current reality of multi-level governance, and the related intersecting levels of membership are particularly picked up in relation to EU citizenship. The growing prominence of the equality principle in these respects, and more particularly the constraints on state sovereignty by the prohibition of discrimination in relation to questions of acquisition and deprivation of nationality is a recurring theme throughout these articles. Another theme that features regularly in this special issue concerns the implications of the new reality of the mobile world, and the related multiplication of migration patterns, for one's understanding of nationality and its implications in (international) law. 
No less than four articles concern (particular aspects of) the acquisition of nationality. David Owen's article 'On the Right to have Nationality Rights: Statelessness, Citizenship and Human Rights' critically analyses the extent to which international law protects a right to have a nationality. The extent to which choices in terms of nationality issues still constitute the last bastion of state sovereignty are obviously a key consideration. He emphasises the crucial importance of this right to a nationality, while drawing extensively on the equality principle, but also identifies various flaws as to the implementation of this right.

René de Groot and Olivier Vonk discuss in their article the global trends regarding the two main systems of acquisition of nationality by birth, namely ius soli and ius sanguinis. The article by Iseult Honohan and Nathalie Rougier continues the focus on global birth right citizenship laws but adds an important focus, more particularly the extent to which these systems realise the inclusion of persons with a migrant origin.

Sabrina Wollmann's article may at first sight have a very specific focus on 'Recent trends in Nationality Requirements in Olympic Sports', it actually picks up an important question, namely the extent to which nationality can be acquired when this is (predominantly) for instrumental reasons. This obviously ties in with the discussion of the underlying rationale of nationality, which also underlies the systems of birth right nationality.

In his article for this special issue, 'The Next Frontier: Dual Nationality as a Multi-Layered Concept', Patrick Wautelet identifies the shifts over time in the baseline approach of international law regarding dual nationality, while calling for a further differentiation in that approach, more particularly considering the different strength of the ties one has with the respective states concerned. The particular position of dual nationals is also focused upon in the article by Laura van Waas and Sangita Jaghai, in which they problematize that dual nationals are differently and disproportionately affected by the recent measures states adopt to deprive persons (suspected from) having engaged in terrorist activities from their nationality.

Helen Oosterom-Staples' article 'The Triangular Relation between Nationality, EU citizenship and Migration in EU Law: A Tale of Competing Competences' addresses the related instance of multiple, intersecting memberships, status and rights. Her discussion confirms the central importance of entry and residence rights (translating into 'intra-EU mobility' rights) to effectuate membership. Her analysis furthermore reveals how de facto pressures flowing from membership in a supranational organization 'guide' states' sovereign choices in relation to nationality issues, where she points to an informal harmonisation process, bringing the conditions for acquisition and loss of nationality in the Member States closer together.

Eileen Denza's article zooms in on one of the protection mechanisms that are contingent on nationality, namely diplomatic protection. She provides a comprehensive account of diplomatic protection, including its meaning, the interrelation with human rights (protection mechanisms), and the specific position of dual nationals and EU citizens. 
The final article is by Teun Struycken and has a private international law dimension. Struycken analyses the reduced significance of nationality/legal citizenship as connecting factor while zooming in on religious family law, and taking due account of the jurisprudence of the ECtHR and the CJEU.

Acknowledgements I would like to thank Michelle Duin, our student assistant, for her excellent research assistance.

Open Access This article is distributed under the terms of the Creative Commons Attribution 4.0 International License (http://creativecommons.org/licenses/by/4.0/), which permits unrestricted use, distribution, and reproduction in any medium, provided you give appropriate credit to the original author(s) and the source, provide a link to the Creative Commons license, and indicate if changes were made.

\section{References}

Anderson B (2017) Imagined communities: reflections on the origin and spread of nationalism, revised edn. Verso, London

Arendt H (1968) The origins of totalitarianism. Harcourt, San Diego/New York/London

Baldi G, Goodman SW (2015) Migrants into members: social rights, civic requirements, and citizenship in Western Europe. West Eur Politics 38(6):1152-1173

Barkey K, Parikh S (1991) Comparative perspectives on the state. Ann Rev Sociol 17(1):523-549

Basdevant J (1909) Conflits de nationalités dans les arbitrages Vénézuéliens de 1903-1905. Revue de Droit International Privé 14(5):41-63

Bauböck R (2009) The rights and duties of external citizenship. Citizsh Stud 13(5):475-499

Bauböck R (2010) Studying citizenship constellations. J Ethn Migr Stud 36(5):847-859

Bauböck R (2015) Ius filiationis: a defence of citizenship by descent. In: Dumbrava C, Bauböck R (eds) Bloodlines and belonging: Time to abandon ius sanguinis? EUI Working Paper RSCAS 2015/80, pp 6-10

Bauböck R, Giraudon V (2009) Realignments of citizenship: reassessing rights in the age of plural membership and multi-level governance. Citizsh Stud 13(5):439-450

Bauböck R, Ersboll E, Groenendijk K, Waldrauch H (2006) Acquisition and loss of nationality: policies and trends in 15 European countries. Amsterdam UP, Amsterdam

Beckman L (2006) Enfranchising citizenship and voting rights: should resident aliens vote? Citizsh Stud 10(2):153-165

Bellamy R (2008) Evaluating Union citizenship: belonging, rights and participation within the EU. Citizsh Stud 12(6):597-611

Benhabib S (2005) Borders, boundaries, and citizenship. Political Sci Politics 38(4):673-677

Bloemraad I (2017) Does citizenship matter? In: Shachar A, Bauböck R et al (eds) The Oxford handbook of citizenship studies. OUP, Oxford, pp 524-550

Bloemraad I, Korteweg A, Yurdakul G (2008) Citizenship and immigration: multiculturalism, assimilation and challenges to the nation-state. Ann Rev Sociol 34:153-179

Boll AM (2005) Nationality and obligations of loyalty in international and municipal law. Aust Yearb Int Law 24:37-64

Bosniak L (2002) Citizenship denationalized (the state of citizenship symposium). Indiana J Global Legal Stud 7(2):447-509

Brubaker R (1992) Citizenship and nationhood in France and Germany. HUP, Harvard

Brubaker R (2004) In the name of the nation: reflections on nationalism and patriotism. Citizsh Stud $8(2): 115-127$

Cole D (2003) Are foreign nationals entitled to the same constitutional rights as citizens? T. Jefferson Law Rev 25:367-388

Coombs M (2005) Kaunda v president of the republic of SA, CCT 23/04. Am J Int Law 99(3):681-686

Crawford J (2012) The relations of nationality. In: Crawford J (ed) Brownlie's principles of public international law. OUP, Oxford, pp 509-526 
De Groot D (2015) Law by blood of blood by law?. In: Dumbrava C, Bauböck R (eds) Bloodlines and belonging: time to abandon ius sanguinis? EUI Working Papers RSCAS 2015/80, pp 29-31

De Groot G-R, Vonk O (2018) Acquisition of nationality by birth on a particular territory or establishment of parentage: global trends regarding ius sanguinis and ius soli. Neth Int Law Rev. https://doi. org/10.1007/s40802-018-0118-5 (in this special issue)

Denza E (2018) Nationality and diplomatic protection. Neth Int Law Rev. https://doi.org/10.1007/s4080 2-018-0119-4 (in this special issue)

De Schutter H, Ypi L (2015) Mandatory citizenship for immigrants. B J Political Sci 45(2):235-251

Diener AC (2017) Rescaling the geography of citizenship. In: Shachar A, Bauböck R et al (eds) The Oxford handbook of citizenship studies. OUP, Oxford, pp 36-59

Dugard J (2009) Diplomatic protection. In Wolfrum R (ed) Max Planck encyclopedia of international law. OUP, online edition, www.mpepil. Accessed 11 Oct 2018

Dugard J (2013) Articles on diplomatic protection. UN audiovisual library of international law. http:// legal.un.org/avl/ha/adp/adp.html. Accessed 11 Oct 2018

Earnest DC (2015) The enfranchisement of resident aliens: variations and explanations. Democratisation 22:861-883

Falk R (2002) Revisiting Westphalia, discovering Post-Westphalia. J Eth 6(4):311-352

Gans G (2017) Citizenship and nationhood. In: Shachar A, Bauböck R et al (eds) The Oxford handbook of citizenship studies. OUP, Oxford, pp 107-128

Gebel HG (2002) The Neolithic of the Near East: an essay on a 'polycentric process' and other current research problems. In: Hausleiter A, Kerner S, Müller-Neuhof B (eds) Material culture and mental spheres: rezeption archäologischer denkrichtungen in der vorderasiatischen altertumskunde. UgaritVerlag, Münster, pp 313-324

Gibney MJ (2017) Denationalization. In: Shachar A, Bauböck R et al (eds) The Oxford handbook of citizenship studies. OUP, Oxford, pp 358-384

Goodman SW (2014) Immigration and membership politics in Western Europe. CUP, Cambridge

Groenendijk K (2008) Local voting rights for non-citizens in Europe: What we know and what we need to know. Migration Policy Institute, Washington

Habermas J (2000) The postnational constellation: political essays. Polity Press, Cambridge

Habib I (1975) Emergence of nationalities. Soc Sci 4:14-20

Honohan I (2017) Liberal and republican conceptions of citizenship. In: Shachar A, Bauböck R et al (eds) The Oxford handbook of citizenship studies. OUP, Oxford, pp 83-106

Honohan I, Rougier N (2018) Global birthright citizenship laws: how inclusive? Neth Int Law Rev. https ://doi.org/10.1007/s40802-018-0115-8 (in this special issue)

Ignatieff M (1987) The myth of citizenship. Queen's Law J 12:399-420

Insin EF, Turner BS (2002) Citizenship studies: an introduction. In: Isin EF, Turner BS (eds) The handbook of citizenship studies. SAGE, London, pp 1-10

Joppke CH (2007) Transformation of citizenship: status, rights, identity. Citizsh Stud 11(1):37-48

Joppke CH (2017) Citizenship in immigration states. In: Shachar A, Bauböck R et al (eds) The Oxford handbook of citizenship studies. OUP, Oxford, pp 385-406

Kesby A (2012) The right to have rights: citizenship, humanity, and international law. OUP, Oxford

Klabbers J (2015) The EJIL foreword: the transformation of international organizations law. Eur J Int Law 26(1):9-82

Kochenov D (2010) Rounding up the circle: the mutation of member states nationalities under pressure from EU citizenship. EUI Working Paper RSCAS 2010/23

Kochenov D (2011) A real European citizenship: a new jurisdiction test: a novel chapter in the development of the Union in Europe. Columbia J Eur Law 18(1):55-109

Kostakopoulou D (2003) Why naturalisation? Perspect Eur Politics Soc 4(1):85-115

Laakso L, Olukoshi AO (1996) The crisis of the post-colonial nation-state project in Africa. In: Olukoshi AO, Laakso L (eds) Challenges to the nation-state in Africa. Nordiska Afrikainstitutet, Uppsala, pp 7-39

Leigh GIF (1971) Nationality and diplomatic protection. Int Comp Law Q 20(3):453-475

Lenard PT (2015) Residence and the right to vote. Int Migr Integr 16:119-132

Liebich A (2010) Is there still an East-West divide in the conception of citizenship in Europe? In: Bauböck J, Liebich A (eds) Is there still an East-West divide in the conception of citizenship in Europe? EUI Working Paper RSCAS 2010/19, pp 1-4

Linklater A (2002) Cosmopolitan citizenship. In: Isin EF, Turner BS (eds) The handbook of citizenship studies. SAGE, London, pp 317-332 
McMahon S (2012) Introduction: developments in the theory and practice of citizenship. In: McMahon S (ed) Developments in the theory and practice of citizenship. CUP, Cambridge, pp 1-20

Miller D (1995) Introduction. In: Miller D (ed) On nationality. Clarendon Press, Wotton-under-Edge, pp $1-16$

O'Cinneide C (2014) Migrant rights under the European Social Charter. In: Costello C, Freedland M (eds) Migrants at work: immigration and vulnerability in labour law. OUP, Oxford, pp 282-302

Oman N (2010) Hannah Arendt's right to have rights: a philosophical context for human security. J Human Rights 9(3):279-302

Oosterom-Staples H (2018) The triangular relationship between nationality, EU citizenship and migration in EU law: a tale of competing competences. Neth Int. Law Rev. https://doi.org/10.1007/s4080 2-018-0122-9 (in this special issue)

Orgad L (2017) Naturalization. In: Shachar A, Bauböck R et al (eds) The Oxford handbook of citizenship studies. OUP, Oxford, pp 337-357

Pennings F, Seeleib-Kaiser M (2018) EU citizenship and social rights: entitlements and impediments to accessing welfare. Edward Elgar, Cheltenham

Rodriguez CM (2009) The citizenship clause, original meaning, and the egalitarian unity of the fourteenth amendment. Univ Pa J Const Law 11(5):1363-1371

Rostek C, Davies G (2006) The impact of Union citizenship on national citizenship policies. European Integration Online Papers 10:1-54

Rubenstein K (2004) Globalisation and citizenship and nationality. In: Dauvergne C (ed) Jurisprudence for an interconnected globe. Taylor \& Francis, Leiden, pp 2-29

Rubenstein K (2007) Rethinking nationality in international law. In: Aceves WJ, Hunnicutt CA, Thomas Ch (eds) Proceedings of the 101st Annual Meeting of the American Society of International Law. American Society of International Law, Washington, pp 99-102

Rubenstein K, Adler D (2000) International citizenship: the future of nationality in a globalised world. Indiana J Global Leg Stud 7(2):519-548

Saffran W (1997) Citizenship and nationality in democratic systems: approaches to defining and acquiring membership in the political community. Int Political Sci Rev 18(3):313-335

Sands P (2016) East West Street. Orion Books, London

Sassen S (2002) Towards post-national and denationalized citizenship? In: Isin EF, Turner BS (eds) The handbook of citizenship studies. SAGE, London, pp 277-292

Scarre C (2005) The world transformed: from foragers and farmers to states and empires. In: Scarre C (ed) The human past: world prehistory \& the development of human societies. Thames \& Hudson, London, pp 176-199

Sejersen TB (2008) I vow to thee my countries The expansion of dual citizenship in the 21 st century. Int Migr Rev 42(3):523-549

Shachar A (2009) The birthright lottery: citizenship and global inequality. HUP, Harvard

Shachar A (2014) Introduction: citizenship and the 'right to have rights'. Citizsh Glob World $18(2): 114-124$

Shachar A, Baub R, Bloemraad I, Vink M (2017) Introduction: citizenship-quo vadis? In: Shachar A, Bauböck R et al (eds) The Oxford handbook of citizenship studies. OUP, Oxford, pp 3-11

Shaw J, Stiks I (2013) What do we talk about when we talk about citizenship rights? In: Shaw J, Stiks I (eds) Citizenship rights. Ashgate Publishing, Farnham, p xi

Smith R (2002) Modern citizenship. In: Isin EF, Turner BS (eds) The handbook of citizenship studies. SAGE, London, pp 105-116

Somers MR (2008) Genealogies of citizenship: markets, statelessness, and the right to have rights. CUP, Cambridge

Spiro PJ (2011) A new international law of citizenship. Am J Int Law 145(4):694-746

Spiro PJ (2017) Multiple citizenship. In: Shachar A, Bauböck R, Bloemraad I, Vink M (eds) The Oxford handbook of citizenship studies. OUP, Oxford, pp 621-643

Tanasoca A (2015) Distributing some, but not all, rights of citizenship according to ius sanguinis. In: Dumbrava C, Bauböck R (eds) Bloodlines and belonging: time to abandon ius sanguinis? EUI Working Papers RSCAS 2015/80, pp 39-42

Tho Pesch S (2015) The influence of human rights on diplomatic protection: reviving an old instrument of PIL. In: Weiss N, Thouvenin JM (eds) The influence of human rights on international law. Springer, New York, pp 55-67

Traunmuller K (2013) 'Kin-states' and 'extraterritorial naturalisation'-some reflections under international law. Austrian Rev Int Eur Law 18:99-152 
Turner BS (2016) We are all denizens now: on the erosion of citizenship. Citizsh Stud 20:679-692

Van Waas L, Jaghai S (2018) All citizens are created equal, but some are more equal than others. Neth Int Law Rev. https://doi.org/10.1007/s40802-018-0123-8 (in this special issue)

Vermeer-Künzli A (2007) As if: the legal fiction in diplomatic protection. Eur J Int Law 18(1):37-68

Vermeersch P (2014) The Romani perspective: experiences and acts of citizenship. In: Insin EF, Nyers P (eds) Routledge handbook of global citizenship studies. Routledge, Abingdon, pp 477-486

Wautelet P (2018) The next frontier: dual nationality as a multi-layered concept. Neth Int Law Rev. https ://doi.org/10.1007/s40802-018-0125-6 (in this special issue)

Wimmer A (2009) Herder's heritage and the boundary making approach: studying ethnicity in immigrant societies. Sociol Theory 27(3):244-270

Wimmer A, Feinstein Y (2010) The rise of the nation-state across the world, 1816-2001. Am Sociol Rev 75(5):764-790

Wollmann AS (2018) Recent trends in nationality requirements in Olympic sports. Neth Int Law Rev. https://doi.org/10.1007/s40802-018-0124-7 (in this special issue) 